\title{
FAKTOR - FAKTOR YANG MEMPENGARUHI KEBERHASILAN USAHA PENGEPUL SAMPAH DI KOTA YOGYAKARTA
}

\author{
Adi Saputra \\ Surahma Asti Mulasari \\ Universitas Ahmad Dahlan \\ rahmasti_fkmuad@yahoo.com
}

\begin{abstract}
This was an observational analytical research with a cross-sectional design. The research subjects were 39 rubbish scavengers. A bivariate analysis result showed that there was an influence of a working motivation towards a business success, there was no influence of business experience towards a business success, and there was an influence of an educational level towards a business success. There was an influence of a working motivation towards a business success, no influence of a business experience towards a business success, and there was an influence of an educational level toward a business success.
\end{abstract}

Keywords: Working Motivation, Business Experience, Educational Level, Business Success, Rubbish Scavengers.

\section{PENDAHULUAN}

Sampah selalu timbul menjadi persolan rumit dalam masyarakat yang kurang memiliki kepekaan terhadap lingkungan. Sampah adalah suatu benda padat yang sudah tidak dipakai lagi oleh pemiliknya atau sudah tidak dimanfaatkan lagi. Sampah dapat berupa senyawa organik maupun senyawa anorganik, berbentuk logam maupun bukan logam, berbentuk bahan yang berasal dari makluk hayati maupun non hayati, yang tidak berguna lagi bagi pemiliknya (Tim Penulis PS, 2011).

Pengusaha sampah (pengepul sampah) merupakan bagian dari sektor informal yang bergerak dalam pengumpulan dan perdagangan sampah layak jual, keberhasilan usaha pengepul sampah dapat dilihat dari tingkat laba yang dihasilkan pada periode tertentu. Laba merupakan selisih antara penghasilan penjualan di atas semua biaya dalam periode tertentu, laba sebesar pengahasilan penjualan dikurangi semua biaya.
Keberhasilan usaha pengepul sampah dapat dipengaruhi oleh beberapa faktor diantaranya ialah, motivasi, pengalaman, tingkat pendidikan, usia, modal usaha, dan lokasi usaha (Tim Penulis PS, 2011).

Menurut observasi dari Badan Lingkungan Hidup tahun 2012, Kota Yogyakarta memiliki jumlah penduduk sebanyak 426.282 orang. Kepadatan rata-rata sebesar 13, 177 jiwa per $\mathrm{km}^{2}$. Hal tersebut menyebabkan jumlah sampah yang terkumpul setiap hari sebanyak 250 ton per hari, dan yang diangkut sebesar 180 ton per hari, sementara tingkat pelayanan BLH sebesar $85 \%$.

Berdasarkan hasil observasi awal yang dilakukan di beberapa usaha pengepul sampah di Kota Yogyakarta, diketahui bahwa ada keuntungan yang dapat dinikmati oleh pengepul dari usaha mengepul sampah. Jenis sampah yang diterima oleh pengepul seperti kertas, plastik, dan logam, didapatkan dari berbagai sumber seperti pemulung, pengepul, office boy, atau juga langsung mencari di pinggiran jalan atau di rumah- 
rumah warga. Berdasarkan hasil wawancara yang dilakukan pada saat observasi, motivasi utama usaha mengepul sampah ini adalah untuk memenuhi kebutuhan hidup keluarga dikarenakan keuntungan yang didapatkan cukup memuaskan, modal usaha tidak besar dan juga resiko kerugian kecil karena sampah-sampah tersebut tidak akan rusak walaupun ditumpuk dalam jangka waktu yang lama. Penelitian ini bertujuan untuk mengetahui faktor-faktor yang mempengaruhi keberhasilan usaha pengepul sampah di Kota Yogyakarta.

\section{REVIEW LITERATUR DAN HIPOTESIS}

\section{Review Literatur}

Ketidakdisiplinan tentang kebersihan dapat menciptakan suasana yang tidak baik. Timbunan sampah akan menyebabkan bau tidak sedap, lalat beterbangan, dan gangguan berbagai penyakit, peluang pencemaran lingkungan disertai penurunan kualitas estetika. Salah satu jenis sampah adalah sampah anorganik. Sampah kering yang membutuhkan waktu cukup lama untuk terurai atau bahkan tidak dapat terurai seperti karet, plastik, kaleng dan logam (Tim Penulis PS, 2011).

Daerah perkotaan menyumbang sampah paling banyak. Hal ini disebabkan banyak faktor, diantaranya pertambahan jumlah penduduk dan arus urbanisasi. Jika persoalan sampah tidak segera ditangani maka pada tahun 2020 volume sampah di Indonesia dapat meningkat hingga 5 kali lipat, yang berarti satu juta ton tumpukan sampah dalam sehari (Simatupang, dkk., 2011).

Pengelolaan sampah sebenarnya telah diatur pemerintah melalui UU NO.18 tahun 2008. Didalamnya termaktub bahwa pengelolaan sampah tidak hanya menjadi kewajiban pemerintah saja. Masyarakat dan pelaku usaha sebagai penghasil sampah juga bertanggung jawab menciptakan lingkungan yang bersih dan sehat. Pemerintah melalui UU tersebut memberi ruang yang cukup banyak bagi pemerintah Provinsi,
Kotamadya/Kabupaten untuk merencanakan dan mengelola sampah dalam kawasannya (UndangUndang Republik Indonesia, Nomor 08 Tahun 2008).

Pengambilan sampah oleh sektor informal menjadi salah satu usaha untuk mengurangi jumlah sampah. Sektor informal ini memiliki jaringan yang cukup luas meliputi pemulung, pengepul, sub suplayer, dan suplayer. Sampah yang diambil oleh pemulung berupa sampah kertas, plastik, logam, dan gelas. Para pemulung merupakan ujung tombak proses daur ulang di Indonesia untuk memanfaatkan kembali sampah. Dari kegiatan pemulung ini akan bermuara pada industri daur ulang sampah (Suparno, 2013). Pengusaha sampah (pengepul sampah) merupakan bagian dari sektor informal yang bergerak dalam pengumpulan dan perdagangan sampah layak jual (Tim Penulis PS, 2011). Menjadi seorang pengepul sampah merupakan peluang bisnis yang cukup menjanjikan. Di Indonesia pemulung biasanya mengambil sampah kertas, plastik, logam, dan gelas. Selain itu sampah yang biasa dimanfaatkan untuk didaur ulang adalah botol bekas, segala macam kertas, alumunium, besi bekas, plastik wadah shampo, botol plastik bekas air mineral. Hal tersebut berpotensi untuk dijadikan sumber penghasilan (Oswari,dkk., 2006).

Dalam konteks penelitian ini, pengepul sampah dipandang sebagai seorang wirausahawan. Wirausahawan adalah orang yang berani mengambil resiko, percaya diri menghadapi tantangan usaha dan permasalahannya, berinisiatif mengembangkan usahanya untuk mencapai tujuan. Wirausahawan memiliki kemampuan manajerial untuk mengorganisir usahanya, mengembangkan strategi operasi, mendapatkan dana, dan mengelola aktivitas bisnis. Keberhasilan usaha diukur dari beberapa hal yaitu kemampuan menguasai pasar, bertahan dalam perasaingan, pendapatan yang lebih, dan bertahan dalam kondisi yang sulit (Machfoedz, M., 2005), 
Delapan langkah menuju puncak karir berwirausaha (Alma, 2009), terdiri atas:

a. Mau bekerja keras (capacity for hard work)

b. Bekerjasama dengan orang lain (getting things done with and through people)

c. Penampilan yang baik (good appearance)

d. Yakin (self confidence)

e. Pandai membuat keputusan (making sound decision)

f. Mau menambah ilmu pengetahuan (college education)

g. Ambisi untuk maju (ambition drive)

Pandai berkomunikasi (ability to communicate)

Hal yang penting bagi pencapaian prestasi individu adalah motivasi. Alma (2009) menerangkan bahwa motivasi adalah kemauan untuk berbuat sesuatu, sedangkan motif adalah kebutuhan, keinginan dan dorongan. Motivasi seseorang tergantung pada kekuatan motifnya, motif dengan kekuatan besar yang akan menentukan perilaku seseorang. Motif yang kuat ini seringkali berkurang apabila telah mencapai kepuasan ataupun karena menemui kegagalan. Motivasi adalah dorongan yang menggerakan manusia untuk melakukan sesuatu (Irwanto, 2002). Hal tersebut senada dengan Nashar (2004) yang mengemukakan motivasi ialah sesuatu yang mendorong seseoranguntuk bertindak melakukan sesuatu.

Meredith (Suryana, 2003) menguraikan aspek-aspek berwirausaha, yaitu:

a. Kemampuan mengindera peluang usaha Kemampuan melihat dan memanfaatkan peluang untuk mengadakan langkah-langkah perubahan menuju masa depan yang lebih baik.

b. Berperilaku memimpin

Mampu mengarahkan, menggerakkan orang lain, dan bertanggungjawab untuk meningkatkan usaha.

c. Memiliki inisiatif untuk menjadi kreatif dan inovatif
Mempunyai prakarsa untuk menciptakan produk/metode baru yang lebih baik mutu atau jumlahnya agar mampu bersaing.

d. Mampu bekerja keras

Memiliki daya juang yang tinggi, bekerja penuh energi, tekun, tabah, melakukan kegiatan untuk mencapai tujuan tanpa mengenal putus asa.

e. Berpandangan luas dengan visi ke depan yang baik,

Berorientasi pada masa yang akan datang dan dapat memperkirakan hal-hal yang dapat terjadi sehingga langkah yang diambil sudah dapat diperhitungkan.

f. Berani mengambil resiko

Suka pada tantangan dan berani mengambil resiko walau dalam situasi dan kondisi yang tidak menentu. Resiko yang dipilih tentunya dengan perhitungan yang matang.

Adapun aspek-aspek yang berpengaruh dalam motivasi berwirausaha menurut Riyanti (2003), yaitu:

1. Kemandirian, kemampuan untuk bisa berdiri sendiri, kritis, dan dinamis bukan berarti tanpa bantuan orang lain dalam bekerjasama.

2. Inovatif, merupakan mental wirausaha, berorientasi ke masa depan, mempunyai hasrat untuk menemukan ide-ide baru, berorientasi pada hasil karya, kemampuan, disiplin, dan bertanggung jawab serta hasrat untuk berprestasi dibidangnya.

3. Menangung resiko, kemampuan untuk bisa menghadapi tantangan dan segala kemungkinan yang terjadi dengan penuh perhitungan, seperti naik turunnya harga, persaingan, dan sebagainya.

Variabel yang lain yang dapat mempengaruhi adalah upaya yang dicurahkan, serta kemampuan dan pengalaman masa lalu (Sofyandi, dkk., 2007). 


\section{Hipotesis}

1. Ada pengaruh motivasi kerja terhadap keberhasilan usaha pengepul sampah di Kota Yogyakarta.

2. Ada pengaruh pengalaman usaha terhadap keberhasilan usaha pengepul sampah di Kota Yogyakarta.

3. Ada pengaruh tingkat pendidikan terhadap keberhasilan usaha pengepul sampah di Kota Yogyakarta.

\section{METODE PENELITIAN}

Penelitian ini merupakan penelitian observasional analitik dengan rancangan penelitian cross sectional (Notoatmodjo, S, 2012). Subyek penelitian ini pengepul sampah yang berjumlah 39 orang. Dalam penelitian ini menggunakan alat ukur berupa kuisioner, panduan wawancara, dan lembar pengamatan. Kuisioner telah melalui uji validitas dan realibilitas yang dilakukan kepada pengepul sampah yang ada di Kabupaten Bantul dan Sleman. Variabel bebas penelitian ini adalah motivasi Kerja, pengalaman, dan tingkat pendidikan pengepul sampah di Kota Yogyakarta. Variabel terikatnya adalah keberhasilan usaha pengepul sampah Kota Yogyakarta yang dilihat dari laba bersih berdasarkan UMK Kota Yogyakarta. Analisis data yang digunakan yaitu analisis univariat (deskriptif) dan analisis bivariat.

\section{HASIL PENELITIAN DAN PEMBAHASAN}

\section{Deskripsi Lokasi Penelitian}

Kota Yogyakarta berkedudukan sebagai ibukota Propinsi DIY dan merupakan satusatunya daerah tingkat II yang berstatus Kota di samping 4 daerah tingkat II lainnya yang berstatus Kabupaten. Kota Yogyakarta terletak ditengah-tengah Propinsi DIY (Pemeritah Kota Yogyakarta, 2013). Jumlah populasi dalam penelitian ini sebanyak 50 pengusaha pengepul sampah. Sampel didapatkan berdasarkan kriteria inklusi dan eksklusi. Kriteria inklusi adalah sebagai berikut :

a. Tempat usaha berlokasi di kota Yogyakarta

b. Pengepul sampah berusia 15-64 tahun

c. Lama Usaha $\geq 5$ tahun

Kriteria ekslusi adalah tidak dapat membaca dan menulis

Berdasarkan kriteria inklusi dan eksklusi tersebut maka didapatkan sampel penelitian sebanyak 39 pengusaha pengepul sampah di Kota Yogyakarta.

\section{Karakteristik Responden}

Karakteristik responden dalam penelitian ini dapat dilihat pada tabel berikut ini :

Tabel 1.

Karakteristik Responden Penelitian

\begin{tabular}{|c|c|c|}
\hline Variabel & $\begin{array}{c}\text { Jumlah } \\
\text { Responden }\end{array}$ & Persentase \\
\hline Umur & 5 & $12,8 \%$ \\
15-30 Tahun & 34 & $87,2 \%$ \\
31-64 Tahun & 32 & $82,1 \%$ \\
\hline Lama Usaha & 7 & $17,9 \%$ \\
5-20 Tahun & \\
\hline
\end{tabular}

Sumber : Data Primer, 2013

Berdasarkan Tabel 1, hasil penelitian terhadap 39 orang jumlah responden, dengan umur minimal 15 tahun dan umur maksimal adalah 64 tahun. Mayoritas rentang umur responden adalah 31-64 tahun yaitu sebanyak 34 orang responden $(87,2 \%)$, Lama usaha dengan minimal usaha 5 tahun dan maksimal 38 tahun. Mayoritas lama usaha responden adalah 5-20 tahun sebanyak 32 responden $(82,1 \%)$. 
Analisis Data

\section{1) Analisis Univariat}

Hasil dari analisis data terlihat pada tabel berikut ini :

Tabel 2.

Hasil analisis univariat

\begin{tabular}{|c|c|c|}
\hline & $\begin{array}{c}\text { Jumlah } \\
\text { (orang) }\end{array}$ & $\begin{array}{c}\text { Persentase } \\
(\%)\end{array}$ \\
\hline $\begin{array}{c}\text { Motivasi } \\
\text { Rendah }\end{array}$ & 4 & $10,3 \%$ \\
Tinggi & 35 & $89,7 \%$ \\
\hline $\begin{array}{c}\text { Pengalaman Usaha } \\
\text { Berpengalaman } \\
\text { Tidak Berpe- }\end{array}$ & 20 & $51,3 \%$ \\
ngalaman & 19 & $48,7 \%$ \\
\hline Tingkat Pendidikan & 14 & $35,9 \%$ \\
Rendah & 25 & $64,1 \%$ \\
Tinggi & 30 & $76,9 \%$ \\
\hline Keberhasilan Usaha & & \\
Berhasil & 9 & $23,1 \%$ \\
\hline Tidak Berhasil & & \\
\hline
\end{tabular}

Sumber : Data Primer, 2013

Berdasarkan tabel di atas, diketahui bahwa sebagian besar responden memiliki motivasi tinggi dalam berusaha yaitu sebanyak 35 orang responden $(89,7 \%)$. Dari 39 responden yang pernah atau sedang menjalankan usaha selain usaha pengepul sampah adalah 20 responden $(51,3 \%)$. Sedangkan yang tidak pernah dan tidak sedang menjalankan usaha selain usaha pengepul sampah adalah 19 responden $(48,7 \%)$. Sebagian besar pengepul sampah memiliki tingkat pendidikan tinggi yaitu 25 orang $(64,1 \%)$ dan yang memiliki tingkat pendidikan rendah 14 orang $(35,9 \%)$. Sebagian besar pengepul sampah berhasil dalam usahanya dengan penghasilan di atas UMK Yogyakarta yaitu 30 orang (76,9\%).

\section{2) Analisis Bivariat}

Hasil analisis bivariat memperole.h hasil sebagai berikut :
Tabel 3.

Hasil Analisis Uji Fisher's Exact Test Pengaruh Motivasi Kerja Terhadap Keberhasilan Usaha Pengepul Sampah Di Kota Yogyakarta 2013

\begin{tabular}{|c|c|c|c|c|c|c|c|c|c|}
\hline & & \multicolumn{4}{|c|}{ Keberhasilan Usaha } & \multirow{3}{*}{$R P$} & \multirow{3}{*}{$P$} & \multicolumn{2}{|c|}{$C I$} \\
\hline \multirow{2}{*}{\multicolumn{2}{|c|}{ Keterangan }} & \multicolumn{2}{|c|}{ Berhasil } & \multicolumn{2}{|c|}{ Tidak Berhasil } & & & \multirow{2}{*}{ Lower } & \multirow{2}{*}{ Upper } \\
\hline & & $\mathrm{n}$ & $\%$ & $\mathrm{n}$ & $\%$ & & & & \\
\hline \multirow{2}{*}{ Motivasi } & Tinggi & 29 & 74,35 & 6 & 15,38 & \multirow[t]{3}{*}{4,375} & \multirow[t]{3}{*}{0,032} & \multirow[t]{3}{*}{1,740} & \multirow[t]{3}{*}{11,003} \\
\hline & Rendah & 1 & 2,56 & 3 & 7,69 & & & & \\
\hline Total & & 30 & 76,91 & 9 & 23,07 & & & & \\
\hline
\end{tabular}

Sumber : Data Primer, 2013

Berdasarkan hasil uji Fisher Exact Test dgn nilai P-value yaitu 0,032 $(0,032<0,05)$. Hal ini menunjukkkan bahwa Ho ditolak dan Ha diterima yang berarti ada pengaruh motivasi terhadap keberhasilan usaha pengepul sampah di Kota Yogyakarta. Berdasarkan nilai Confident Interval 95\% dengan nilai lower dan upper 1,740 $>1<11.003$ (tidak melewati/mencakup angka 1). Hal ini menunjukkan bahwa Ho ditolak dan Ha diterima yang berarti ada pengaruh motivasi terhadap keberhasilan usaha pengepul sampah di Kota Yogyakarta. Dilihat dari nilai Rasio Prevalent yaitu 4,375 hal ini berarti responden yang memiliki motivasi rendah mempunyai resiko 4,375 kali lebih besar untuk tidak mencapai keberhasilan usaha dibandingkan dengan responden yang memiliki motivasi tinggi.

Tabel 4.

Hasil Analisis Uji Fisher's Exact Test

Pengaruh Pengalaman Terhadap

Keberhasilan Usaha Pengepul Sampah Di Kota Yogyakarta 2013.

\begin{tabular}{|c|c|c|c|c|c|c|c|c|c|}
\hline \multirow{2}{*}{\multicolumn{2}{|c|}{ Keterangan }} & \multicolumn{4}{|c|}{ Keberhasilan Usaha } & \multirow{2}{*}{$R P$} & \multirow{2}{*}{$P$} & \multicolumn{2}{|c|}{$C I$} \\
\hline & & \multicolumn{2}{|c|}{ Berhasil } & \multicolumn{2}{|c|}{$\begin{array}{l}\text { Tidak } \\
\text { Berhasil }\end{array}$} & & & Lower & Upper \\
\hline \multirow{2}{*}{$\begin{array}{l}\text { Pengalaman } \\
\text { Usaha }\end{array}$} & Berpengalaman & 15 & 38,46 & 4 & 10,25 & 1,18 & 1,000 & 0,374 & 3,770 \\
\hline & $\begin{array}{l}\text { Tidak } \\
\text { berpengalaman }\end{array}$ & 15 & 38,46 & 5 & 12,82 & & & & \\
\hline Total & & 30 & & 9 & & & & & \\
\hline
\end{tabular}

Sumber : Data Primer, 2013

Berdasarkan hasil uji Fisher Exact Test dgn nilai $\mathrm{P}$-value yaitu $1,000(1,000>0,05)$. Hal ini menunjukkkan bahwa Ho diterima dan Ha ditolak yang berarti tidak ada pengaruh pengalaman 
usaha terhadap keberhasilan usaha pengepul sampah di Kota Yogyakarta. Berdasarkan nilai Confident interval 95\% dengan nilai lower dan upper $0,374<1<3,770$ (melewati/mencakup angka 1). Hal ini menunjukkan bahwa Ho diterima dan Ha ditolak yang berarti tidak ada pengaruh pengalaman usaha terhadap keberhasilan usaha pengepul sampah di Kota Yogyakarta.

Tabel 5.

\section{Hasil Analisis Uji Fisher's Exact Test} Pengaruh Tingkat Pendidikan Terhadap Keberhasilan Usaha Pengepul Sampah Di Kota Yogyakarta 2013.

\begin{tabular}{|c|c|c|c|c|c|c|c|c|c|}
\hline \multirow{3}{*}{\multicolumn{2}{|c|}{ Keterangan }} & \multicolumn{4}{|c|}{ Keberhasilan Usaha } & \multirow{3}{*}{$R P$} & \multirow{3}{*}{$P$} & \multicolumn{2}{|c|}{$C I$} \\
\hline & & \multicolumn{2}{|c|}{ Berhasil } & \multirow{2}{*}{\multicolumn{2}{|c|}{$\begin{array}{c}\text { Tidak } \\
\text { Berhasil } \\
\end{array}$}} & & & \multirow[b]{2}{*}{ Lower } & \multirow[b]{2}{*}{ Upper } \\
\hline & & $\mathrm{n}$ & $\%$ & & & & & & \\
\hline Tingkat & Tinggi & 23 & 58,97 & 2 & 5,12 & \multirow{3}{*}{6,250} & \multirow{3}{*}{0,005} & \multirow{3}{*}{1,497} & \multirow{3}{*}{26,085} \\
\hline Pendidikan & Rendah & 7 & 17,94 & 7 & 17,94 & & & & \\
\hline Total & & 30 & & 9 & & & & & \\
\hline
\end{tabular}

Sumber : Data Primer, 2013.

Berdasarkan hasil uji Fisher Exact Test dgn nilai P-value yaitu $0,005(0,005<0,05)$. Hal ini menunjukkkan bahwa Ho ditolak dan Ha diterima yang berarti ada pengaruh tingkat pendidikan terhadap keberhasilan usaha pengepul sampah di Kota Yogyakarta. Berdasarkan nilai Confident interval 95\% dengan nilai lower dan upper 1,497 $>1<26,085$ (tidak melewati/mencakup angka 1). Hal ini menunjukkan bahwa Ho ditolak dan Ha diterima yang berarti ada pengaruh tingkat pendidikan terhadap keberhasilan usaha pengepul sampah di Kota Yogyakarta. Dilihat dari nilai Rasio prevalent yaitu 6,250 hal ini berarti responden yang memiliki tingkat pendidikan rendah mempunyai resiko 6,250 kali lebih besar untuk tidak mencapai keberhasilan usaha dibandingkan dengan responden yang memiliki tingkat pendidikan tinggi.

\section{Pembahasan}

a. Pengaruh motivasi terhadap keberhasilan usaha pengepul sampah di Kota Yogyakrata

Berdasarkan analisis bivariat pengaruh motivasi terhadap keberhasilan usaha pengepul sampah di Kota Yogyakarta, dari 39 responden yang diteliti, responden yang memiliki motivasi tinggi dan berhasil dalam usaha pengepul sampah adalah sebanyak 29 orang $(74,35 \%)$, responden yang memiliki motivasi tinggi dan tidak berhasil dalam usaha pengepul sampah adalah sebanyak 6 orang $(15,38 \%)$, responden yang memiliki motivasi rendah dan berhasil dalam usaha pengepul sampah adalah sebanyak $1(2,56 \%)$, dan responden yang memiliki motivasi rendah dan tidak berhasil dalam usaha adalah sebanyak 3 orang (7,69\%). Keberhasilan usaha dilihat dari laba bersih yang didapatkan oleh pengepul sampah dalam satu bulan yang kemudian dibandingkan dengan UMK (Upah Minimum Kota/Kabupaten) Yogyakarta 2012 yaitu sebesar Rp 1.065.247.

Berdasarkan hasil uji menunjukkkan bahwa Ho ditolak dan Ha diterima yang berarti ada pengaruh motivasi terhadap keberhasilan usaha pengepul sampah di Kota Yogyakarta. Dilihat dari nilai Rasio Prevalent yaitu 4,375 hal ini berarti responden yang memiliki motivasi rendah mempunyai resiko 4,375 kali lebih besar untuk tidak mencapai keberhasilan usaha dibandingkan dengan responden yang memiliki motivasi tinggi. Motivasi merupakan salah satu faktor individual dari seorang wirausaha. Pengepul sampah merupakan salah satu wirausaha karena menjalankan usahanya sendiri di bidang pengumpulan sampah.

Hal tersebut sesuai dengan pernyataan bahwa kegiatan yang dapat dijadikan usaha alternatif dalam rangka peningkatan pendapatan keluarga antara lain yaitu pengomposan, pengepul kantong plastik, dan daur ulang kertas. Sampah merupakan peluang bisnis yang patut diperhitungkan (Susilo, Ferdinand, 2011).

Motivasi untuk mengembangkan usaha menjadi pendorong untuk melakukan inovasi sehingga usahanya semakin maju dan memperoleh keuntungan yang semakin besar. Semakin bertambahnya jumlah 
penduduk dan kegiatan di Kota Yogyakarta, menyebabkan banyak pula sampah yang dihasilkan. Hal tersebut merupakan peluang bisnis bagi masyarakat yang mencermatinya. Banyaknya pengusaha-pengusaha baru yang bergelut dengan sampah menjadikan persaingan semakin ketat dalam usaha sampah. Sehingga motivasi untuk terus maju dan mengembangkan usaha semakin tinggi dan menjadikan faktor yang berpengaruh untuk mencapai keberhasilan dalam usaha.

Motivasi merupakan salah satu faktor yang mempengaruhi keberhasilan usaha. ${ }^{7}$ Akan tetapi faktor internal wirausaha pun dapat menjadi kendala bagi pertumbuhan usaha. Hal ini disebabkan karena tidak semua wirausaha menginginkan pertumbuhan usaha yang dimilikinya. Hal tersebut kemungkinan karena keinginan tidak ingin melepakan kendala adinistratif, beban kerja yang semakin berat, atau kehilangan kepuasan kerja. Motivasi yang kuat akan berkorelasi dengan keinginan yang lebih kuat pula untuk berkembang (Inggarwati, dan Kaudin. 2010).

\section{b. Pengaruh pengalaman usaha terhadap keberhasilan usaha pengepul sampah di Kota Yogyakarta}

Berdasarkan hasil uji bivariat pengaruh pengalaman usaha terhadap keberhasilan usaha pengepul sampah di Kota Yogyakarta, dari 39 responden yang diteliti, responden yang berpengalaman dan berhasil dalam usaha pengepul sampah sama dengan responden yang tidak berpengalaman dan berhasil dalam usaha pegepul sampah yaitu sebanyak 15 orang $(38,46 \%)$, respoden yang berpengalaman dan tidak berhasil dalam usaha pengepul sampah yaitu 4 orang (10,25\%), sedangkan responden yang tidak berpengalaman dan tidak berhasil dalam usaha pengepul sampah yaitu 5 orang $(12,82 \%)$.
Berdasarkan hasil uji Fisher Exact Test menunjukkkan bahwa Ho diterima dan $\mathrm{Ha}$ ditolak yang berarti tidak ada pengaruh pengalaman usaha terhadap keberhasilan usaha pengepul sampah di Kota Yogyakarta. Hal tersebut kemungkinan disebabkan oleh adanya faktor-faktor pengganggu yang tidak diteliti oleh peneliti seperti modal usaha, jumlah tenaga kerja, pembukuan yang tentunya dapat mempengaruhi hasil dari penelitian. Modal usaha memiliki pengaruh positif dan signifikan terhadap keberhasilan usaha, sehingga apabila modal baik maka keberhasilan usaha juga akan mengalami peningkatan. Begitu juga dengan jumlah tenaga kerja apabila jumlah tenaga kerja semakin baik maka keberhasilan usaha juga akan mengalami peningkatan.

Faktor yang mempengaruhi keberhasilan usaha diantaranya adalah besarnya usaha (volume usaha) dan besarnya modal (biaya usaha). (Makhdalena, 2009) menyatakan bahwa secara simultan velume usaha dan biaya usaha berpengaruh terhadap keberhasilan usaha dan sisanya dipengaruhi faktor lain yang tidak diteliti.

Dalam penelitian ini pengalaman kerja tidak mempengaruhi keberhasilan usaha pengepul sampah. Hal ini kemungkinan disebabkan karena pengalaman usaha dalam penelitian ini hanya melibatkan pengalaman mengurus usaha lain selain sampah. Padahal pengalaman usaha meliputi pula lama melakukan usaha.

Hasil penelitian ini bertentangan dengan Teori Haswell et al. dalam Basrowi yang menyatakan bahwa alasan utama kegagalan usaha adalah kurangya kemampuan manajerial dan pengalaman. Wood dalam Basrowi juga menyatakan bahwa kurangnya pengalaman adalah salah satu penyebab kegagagalan usaha (Basrowi, 2011). 
Hasil penelitian ini bertentangan dengan teori yang menyebutkan bahwa keberhasilan atau prestasi dipengaruhi salah satunya oleh pengalaman kerja (Sofyandi, dkk., 2007). Hasil penelitian ini juga bertentangan dengan penelitian yang dilakukan di Kota Banjarmasin pengalaman berkorelasi signifikan terhadap pendapatan pemulung. Pemulung yang semakin mahir dan terbiasa dalam memilah dan memungut sampah maka hasil pulungannya akan semakin meningkat (Qomariah,dkk., 2011).

\section{c. Pengaruh tingkat pendidikan terhadap keberhasilan usaha pengepul sampah di Kota Yogyakarta}

Berdasarkan hasil uji bivariat pengaruh tingkat pendidikan terhadap keberhasilan usaha pengepul sampah di Kota Yogyakarta, adapun tingkat pendidikan berdasarkan ketentuan pemerintah wajib belajar 9 tahun, tingkat pendidikan tinggi $\geq$ tamat SMP/ sederajat, tingkat pendidikan rendah $\leq \mathrm{SMP} /$ sederajat, dari 39 responden yang diteliti, responden yang memiliki tingkat pendidikan tinggi dan berhasil dalam usaha pengepul sampah adalah sebanyak 23 orang $(58,97 \%)$, responden yang memiliki tingkat pendidikan tinggi dan tidak berhasil dalam usaha pengepul sampah adalah sebanyak 2 orang $(5,12 \%)$, responden yang memiliki tingkat pendidikan rendah dan berhasil sama dengan responden yang memiliki tingkat pendidikan rendah dan tidak berhasil dalam usaha pengepul sampah yaitu sebanyak 7 orang $(17,94 \%)$.

Berdasarkan hasil uji Fisher Exact Test menunjukkkan bahwa Ho ditolak dan Ha diterima yang berarti ada pengaruh tingkat pendidikan terhadap keberhasilan usaha pengepul sampah di Kota Yogyakarta. Berdasarkan hasil uji di atas maka peneliti menganalisis bahwa adanya pengaruh tingkat pendidikan terhadap keberhasilan usaha pengepul sampah di Kota Yogyakarta disebabkan oleh tingkat pengetahuan responden mengenai suatu usaha cukup baik. Pengetahuan baik memungkinkan usaha pengepul sampah sehingga dapat dikelola dengan baik, selalu berinovasi dan mencari peluang untuk terus meningkatkan dan mengembangkan usahanya dengan berbagai cara demi kelangsungan hidup dan keberhasilan usaha di masa yang akan datang.

Teori menyebutkan bahwa kemampuan individu mempengaruhi prestasi kerja (Sofyandi, dkk., 2007). Kemampuan individu salah satunya didapatkan dari pendidikan yang diperoleh. Dalam pengelolaan sampah tingkat pendidikan mempengaruhi perilaku pengelola sampah. Hal ini dibuktikan oleh penelitian di Dusun Padukuhan Desa Sidokarto Kecamatan Godean Kabupaten Sleman Yogyakarta bahwa ada hubungan tingkat pengetahuan terhadap perilaku masyarakat dalam mengelola sampah (Mulasari, S.A. 2012).

Hasil penelitian ini bertentangan dengan penelitian (Qomariah,dkk., 2011), yang menyatakan bahwa tingkat pendidikan tidak berpengaruh secara signifikan terhadap keberhasilan pemulung di Kota Banjarmasin. Ketidaksesuaian tersebut kemungkinan disebabkan karena yang diteliti dalam penelitian Qomariah adalah pemulung sedangkan dalam penelitian ini adalah pengepul sampah.

Pemulung adalah orang yang mengumpulkan bahan baku daur ulang (sampah) dan menjualnya ke lapak (pengepul). Lapak berperan dalam menyortir barang bekas berdasarkan klasifikasi yang diminta oleh produsen daur ulang. Pengepul mengelola tempat luas untuk mengumpulkan barang bekas dan mengkoordinasi para pemulung (Wahyono, S. 2001). 
Pemulung cenderung melakukan kegiatan kerja yang tidak membutuhkan keterampilan khusus, inovasi, ataupun kreatifitas. Pemulung adalah pekerja lapangan, sedangkan pengepul lebih banyak bekerja dalam hal menajerial kegiatan pemulung. Dalam kegiatan manajerian dan pengambangan usaha, pengepul membutuhkan pengetahuan dan pendidikan selain faktor yang lain. Dengan kata lain bahwa pengepul sampah adalah seorang wirausahawan.

Kehadiran sektor informal, seperti para pengepul sampah dan pemulung dalam kegiatan pengelolaan sampah memberikan peran yang cukup besar terhadap berkurangnya sampah yang harus diolah di Tempat Pembungan Akhir (TPA). Peran sektor informal tersebut dapat meningkatkan kebersihan lingkungan, mengurangi sampah dan meminimalisasi kerusakan lingkungan di TPA.

Pekerjaan memulung sampah dinilai positif karena keberadaan pemulung dapat memberikan kontribusi bagi pemerintah terhadap kebersihan serta kontribusi dalam menciptakan lapangan kerja. Dan yang utama adalah dapay mengurangi volume sampah di TPA dan untuk mengawali proses daur ulang (Tim Penulis PS, 2011).

Hal tersebut didukung oleh penelitian (Qomariah,dkk., 2011) bahwa apabila dalam setiap harinya tidak melakukan pemilahan maka akan ada lebih dari 150 ton sampah yang harus dimusnahkan setiap harinya di Kota Banjarmasin. Terdapat tiga pos penting yang berperan dalam pengelolaan sampah yaitu pemulung, pengepul dan pabrik. Ketiganya memiliki hubungan yang cukup erat dan tuidak dapat dipisahkan. Sektor ini secara tidak langsung membantu menjaga kebersihan, kerusakan, dan mengurangi debit sampah.

Hasil serupa ditemukan dalam penelitian di Kabupaten Boyolali bahwa pemulung menjadi salah satu sektor informal yang membantu mengurangi volume sampah yang dibuang ke
TPA. Para pemulung beroperasi di TPS-TPS untuk mengumpulkan sampah anorganik yang laku dijual (Haryono dan Rohmad, 2013). Sampah yang dikelola dengan baik akan meningkatkan nilai ekonomisnya. Sampah dapat dimanfaatkan semaksimal mungkin dan akan membuka lapangan kerja (Gultom, O., 2000). Banyak barang yang dapat diterima pengepul dalam kondisi apapun, baik utuh ataupun rusak, bahkan pecah belah. Barang tersebut berupa kertas, kardus, logam kuningan, alaumunium, besi, tembaga, aki, koran, mika, kaca, karung, dan segala jenis plastik kecualai plastik kemasan makanan/snack/shampo, pengharum dan yang lain (Rachmayanti, dkk., 2013).

\section{KESIMPULAN DAN SARAN}

\section{Kesimpulan}

1. Ada pengaruh motivasi kerja terhadap keberhasilan usaha pengepul sampah di Kota Yogyakarta

2. Tidak ada pengaruh pengalaman usaha terhadap keberhasilan usaha pengepul sampah di Kota Yogyakarta

3. Ada pengaruh tingkat pendidikan terhadap keberhasilan usaha pengepul sampah di Kota Yogyakarta

\section{Saran}

1. Bagi pemerintah Kota Yogyakarta hendaknya memberikan perhatian atau penghargaan kepada pengepul sampah yang telah membantu pemerintah dalam mengurangi jumlah pengangguran dan menangani permasalahan sampah di Kota Yogyakarta.

2. Bagi peneliti selanjutnya diharapkan untuk dapat meneliti faktor-faktor yang mempengaruhi keberhasilan usaha pengepul sampah dengan cara menambah variabel bebas atau mengendalikan variabel-variabel pengganggunya seperti modal, dan jumlah tenaga kerja. 


\section{DAFTAR PUSTAKA}

Alma, B. (2009). Kewirausahaan. Bandung: Alfabeta

Basrowi, 2011, Kewirausahaan Untuk Perguruan Tinggi, Ghalia Indonesia, Bogor. Hal. 19-21.

Gultom, O., 2000, "Pengelolaan Sampah Padat Perkotaan Secara Terpadu", Buletin Limbah, 5 (1) : 7-14.

Haryono., Rohmad, H. 2013, "Indentifikasi Pengelolaan Sampah Kota yang Berbasis Partisipasi Peran Aktif Keluarga dan Pemulung", JKB, No.12. Tk. VII : 1-17.

Inggarwati, K. Kaudin, K. 2010. "Peranan FaktorFaktor Individual Dalam Mengembangkan Usaha”. Jurnal Manajemen Bisnis. 3 (2). Agustus-September : 185-202.

Irwanto, (2002), Psikologi umum. PT Prenhallindo, Jakarta.

Machfoedz, M., Machfoedz, M., 2005, Kewirausahaan : Metode, Manajemen, dan Implementasi, Penerbit BPFEYoyakarta.

Makhdalena, 2009, "Pengaruh Volume Usaha dan Biaya Usaha Terhadap Keberhasilan Usaha Pada Kopkar di Kota Batam”. Jurnal Akuntansi FE Unsil. 4 (1): ISSN : 1907-9958.

Mulasari, S.A. 2012. "Hubungan tingkat Pengetahuan dan Sikap Terhadap Perilaku Masyarakat dalam Mengelola Sampah Di Dusun Padukuhan Desa Sidokarto Kecamatan Godean Kabupaten Sleman Yogyakarta". Jurnal Kesmas. Fakultas Kesehatan Masyarakat UAD. 6 (3) : 204-211.

Nashar H, (2004), Peranan motivasi dan kemampuan awal, Delia Press, Jakarta.
Notoatmodjo, S, 2012, Metodelogi Penelitian Kesehatan, Edisi Revisi Cetakan Kedua, Penerbit PT Rineka Cipta, Jakarta. Hal. 39-40.

Oswari, Suyanto, Susilowati, 2006, "Potensi Nilai Ekonomis Pengelolaan Sampah Kota Depok", Jurnal Ekonomi \& Bisnis, 2 (11) : 59-69.

Pemerintah Kota Yogyakarta, 2013, Kondisi Geografis Kota Yogyakarta, http://www. jogjakota.go.id/, diakses 20 Mei 2013 di Yogyakarta.

Qomariah,E.S., Rahmawati, E., Abdurrahman, Peran, S.B., 2011, "Nilai Ekonomi Sampah Anorganik Yang Di Reduksi Pemulung Dan Faktor Yang Mempengaruhinya Di Tempat Pembuangan Akhir (TPA) Basirin Kota Banjarmasin", EnviroScienteae, Volume 7 : 69-78. ISSN 1978-8096.

Rachmayanti, A.T., Putra, H.P., Kasam., 2013, "Studi Pengelolaan Sampah Anoganik Dalam Rangka Peningkatan Pendapatan Masyarakat (Studi Kasus Daerah Sembungan, Cangkringan Sleman, Kelurahan Demgangan Yogyakarta, Dan Bank Sampah Project B Indonesia)" Prosiding Seminar Nasional Menuju Masyarakat Madani dan Lestari, ISBN: 978-979-98438-8-3 : 345-352.

Riyanti, B.P.D, 2003, Kewirausahaan dari sudut pandang psikologi kepribadian, Grasindo, Jakarta.

Simatupang, Delthy Sugriady., Gunsairi., Rachmat Mardiana., Novie Andriani., Mohammad Taufiq Rinaldi., Ade Hendra Putra., 2011, Manajemen Pengolahan Sampah Berbasis Mandiri, Sustaining Partnership, Jakarta. 
Sofyandi, H., Garniwa, I. 2007, Perilaku Organisasi, Perebit Graha Ilmu Yogyakarta.

Suparno, 2013, "Usaha Daur Ulang dan Produksi Kompos dari Pengelolaan Sampah TPA". Jurnal ORBITH. 9 (2). Juli ; 135146.

Suryana, 2003, Kewirausahaan, edisi revisi, Salemba Empat, Jakarta.

Susilo, Ferdinand, 2011, "Pengelolaan Sampah Terpadu Sebagai Peluang Bisnis Rumah Tangga Di Kota Medan”, Jurnal Pertanian \& Biologi, 3 (1) : 1-15.
Tim Penulis PS, 2011, Penanganan Dan Pengolahan Sampah, Penebar Swadaya, Jakarta.

Undang-Undang Republik Indonesia, Nomor 08 Tahun 2008, Tentang Sistem Pengolahan Sampah.

Wahyono, S. 2001, "Pengelolaan Sampah Kertas di Indonesia", Jurnal Teknologi

Lingkungan, 2 (3) : 276-280. 